\title{
Species Identification of Molluscs and Crustaceans by Means of Latex Agglutination Test ${ }^{* 1}$
}

\author{
Akimi SuzUKI*2, Juami YAMAdA ${ }^{* 2}$, and Julie M. MACARANAS*8 \\ (Received November 5, 1980)
}

\begin{abstract}
Latex (Lx) agglutination tests have been employed in species identification of molluscs and crustaceans. The tests were performed by slide glass method, and $0.5 \%$ suspension of polystyren $\mathrm{Lx}$ particles, were used for the tests. In general, antiserums of rats immunized with sarcoplasmic proteins of molluscs and crustanceans specifically agglutinated the Lx coated with homologous sarcoplasmic antigens, but some cross reactions were detected between the related species. To confirm the species specificity of reactions, the agglutination inhibition tests were made by adding the inhibiting antigen solution (muscle extract) into the agglutination reaction systems. The tesults showed that the identification of species was possible through these tests, when the suitable specific antiscrum was used.

Lx coated with antibody of rat immune serum was also specifically agglutinated by homologous antigen solution.

It was concluded that the $\mathbf{L x}$ agglutination test is very useful in identifying the species, since the reaction was very specific and much more sensitive in comparison with the micro-immunodiffusion method. However, in the development of other studies using $\mathrm{Lx}$ aggiutination, further investigation has to be carried out especially on the problems concerned with the unspecific agglutination accurring with muscle extracts of some teleost species.
\end{abstract}

Polystyrene latex (Lx) particles do not possess antigenic properties and easily adsorb antigen or antibody proteins. The Lx-adsorbed antigen or antibody, namely, the sensitized Lx particles, are rather stable and are agglutinated very sensitively and specifically by homologous antibody or antigen. Consequently, the agglutination test of sensitized $L x$ has been used for detection of rheumatoid factor ${ }^{1,2)}$, histoplasmosis ${ }^{3)}$, blood group substance $^{4)}$, hog cholera virus ${ }^{5)}$ and antiplague antibody $y^{\text {) }}$.

In the course of an investigation on the species specificity of sarcoplasmic proteins of fish, one of the authors ${ }^{7)}$ noted that the $\mathrm{Lx}$ agglutination test may be useful in identifying the fish species. Thus the present work is a continuation of previous preliminary investigations. However, because the muscle extracts of several kinds of fish such as scombroid species, agglutinate Lx unspecifically, and because factors concerned with this phenomenon have been unknown up to date, this report does not deal with teleosts, but with molluscan and crustacean species only.

\section{Materials and Methods}

\section{Muscle Extracts}

Skeletal muscle samples taken from the shell fish which were mostly purchased at Tokyo Central Wholesale Fish Market, were minced by kitchenknife. For use in immunization, minced meat was taken into the polyethylene bottle together with twofold volumes of $0.9 \%$ saline and kept at $-40^{\circ} \mathrm{C}$ for a few days. Then the thawed samples were filtered by gauze and filtrates were centrifuged at $12,000 \mathrm{rpm}$ for $30 \mathrm{~min}$. The supernatant solutions were kept at $-80^{\circ} \mathrm{C}$ or $-40^{\circ} \mathrm{C}$. For agglutination reactions, instead of saline, glycine buffer solution (in two liters: glycine $7.5 \mathrm{~g}, \mathrm{NaCl} 5.8 \mathrm{~g}$, sodium azide $2.0 \mathrm{~g}$, adjusted to $\mathrm{pH} 8.2$ with $\mathrm{NaOH}$ ) was used for extraction.

\section{Lx Particles}

For antigen-sensitized $\mathbf{L x}$ agglutination test, SDL 43 (dia. $0.7 \mu \mathrm{m}$ ) was used, while for antibodysensitized $\mathrm{Lx}$ agglutination test, SDL 73 (dia. $0.35 \mu \mathrm{m})$ was used; these were purchased from Takeda Chemical Industries, Ltd.

*1 Contribution No. B-692 from Tokai Reg. Fish. Res. Lab.

*2 Tokai Regional Fisheries Research Laboratory, 5-1 Kachidokj-5, Chuo-ku, Tokyo 104, Japan (錊木秋 策・山田充阿弥: 東海区本産研究所)。

*8 Marine Sciences Center, University of the Philippines, Diliman, Quezon City, Philippines. 


\section{Immunization Schedules}

Wister strain rats, weighing more than $100 \mathrm{~g}$, mostly about $200 \mathrm{~g}$, were immunized as follows. An aliquot of muscle extract was mixed with an equal volume of complete Freund's adjuvant (Difco Lab.), injected intraperitoneally to each rat, and also hypodermically at several sites of its back. The injections were repeated one or two times, for about 2 week intervals. 2 to $20 \mathrm{mg}$ of sarcoplasmic proteins were injected at one time. 5 to $10 \mathrm{~m} /$ of heparinized blood were collected from the hepatic artery one week after the last injection, and the antiserums separated centrifugally from blood were stored at $-80^{\circ} \mathrm{C}$.

\section{Preparation of Sensitized $L x$}

Sensitization of latex was performed by the method of Matsuzawa et al. ${ }^{B}$ and Kimura and MATSUZAWA $^{\text {Q; }}$, with a modification of some details.

Antigen-sensitized $\mathrm{Lx}$ : One $\mathrm{ml}$ of muscle extract, diluted to 0.1 or $0.2 \mathrm{mg}$ protein $/ \mathrm{ml}$ with the above mentioned glycine buffer was taken into a centrifuge tube and mixed with $1 \mathrm{ml}$ of $1 \% \mathrm{Lx}$ (SDL 43) and $0.4 \mathrm{ml}$ of $5 \%$ bovine serum albumin (SIGMA, dissolved in glycine buffer). After vigorous shaking by the test tube shaker for about several seconds, the tubes were kept in the refrigerator overnight. $10 \mathrm{~m} l$ of $0.2 \%$ bovine serum albumin in glycine buffer solution was put into each tube and the mixtures were centrifuged at $7,000 \mathrm{rpm}$ for $15 \mathrm{~min}$. Supernatants were discarded and to every tube was added $2 \mathrm{~m} /$ of glycine buffer to make a $0.5 \%$ sensitized Lx suspension.

Antibody-sensitized Lx: In this case, either the immune serum solution, diluted 60 fold by glycine buffer, or a $0.3 \mathrm{mg} / \mathrm{m} l$ solution of crude $\gamma$-globulin prepared by the rivanol ammonium sulphate procedure $^{10)}$ was used for sensitizing Lx SDL 73. Sensitization procedures were the same as in the preparation of the antigen-sensitized Lx.

\section{Lx Agglutination Test}

All experiments were performed by slide glass method as follows. Antigen-sensitized Lx agglutination tests were made by putting 1 drop of serum dilution together with 1 drop of $0.5 \%$ sensitized Lx suspension on the well of the glass, mixing them in the glass plate, and keeping them in a humidity box at room temperature, Degrees of agglutination were recorded after 15,30 , and $60 \mathrm{~min}$, with occasional shaking of the glass plates. Antibody-sensitized $\mathrm{Lx}$ agglutination tests were made by putting 1 drop of muscle extract solution to- gether with 1 drop of $0,5 \%$ antibody-sensitized Lx suspension on the well of the glass plate. Other techniques were the same as in the antigensensitized agglutination test.

\section{Agglutination Inhibition Test}

This was made by putting 1 drop of inhibiting antigen solution (muscle extract) together with 1 drop of diluted antiserum on the well of the glass plate, and mixing both solutions by shaking the plate. After $15 \mathrm{~min}, 1$ drop of antigen-sensitjzed Lx suspension was added to the well and the plate was kept in a humidity box at room temperature. Degrees of agglutination were recorded after $1 \mathrm{~h}$.

\section{Micro-Immunodiffusion}

Microscope slides $(26 \times 76 \mathrm{~mm})$ covered with $2 \mathrm{ml}$ of melted $0.7 \%$ agarose (agarose LE, Miles Lab. Inc. was dissolved in a hot solution of $0.9 \%$ $\mathrm{NaCl}-6.2 \mathrm{~mm}$ borate buffer, $\mathrm{pH} 8.2$ ) were used for this test. Peripheral wells and a central well of $4.0 \mathrm{~mm}$ in diameter were cut at $3.0 \mathrm{~mm}$ distances in the agarose gel, and were filled with antiserum or muscle extract respectively. The slides were kept in a humid chamber at room temperature. The precipitation lines developed by antigen-antibody interactions were recorded after 4 and $24 \mathrm{~h}$.

\section{Results}

\section{Antigen-Sensitized Lx Agglutination}

Molluscs: Results of the agglutination tests between the anti-akagai immune serum and the Lx sensitized with muscle extracts of several kinds of molluses are shown in Table 1. The titer of this serum for akagai antigen was distinctly high ( $n=9$, i.e. 512 ) in comparison with those for the other species. The specificity of these reactions were confirmed by carrying out the agglutination inhibition tests, As shown in Table 2, the extract of akagai inhibited agglutination reaction very specifically, but those of the other species failed to inhibit the reaction.

The species specificity of the anti-yariika immune serum was also revealed by the $\mathbf{L x}$ agglutination and the agglutination inhibition tests (see Tables 3 and 4). As shown by the above mentioned instances, the identification of species was possible through Lx agglutination test, when the suitable specific antiserum was used. However, in the case of the immune serum containing very active cross reacting antibodies, it was difficult to identify the 
Table 1. Latex agglutination tests using various dilutions of anti-akagai (arkshell) immune rat serum and the latex particles sensitized with molluse muscle extracts

\begin{tabular}{|c|c|c|c|c|c|c|c|c|c|c|}
\hline \multirow{2}{*}{$\begin{array}{l}\text { Latex (SDL 43) sensitized } \\
\text { with*2 }\end{array}$} & \multirow[b]{2}{*}{$n:$} & \multicolumn{8}{|c|}{ Dilution of antiserum $\left(1 / 2^{n}\right)$} & \multirow[b]{2}{*}{ Control } \\
\hline & & 3 & 4 & 5 & 6 & 7 & 8 & 9 & 10 & \\
\hline (1) Akagai (arkshell) & & 井 & H & \# & 世 & H & + & $\mathrm{t}$ & - & $-*$ \\
\hline (2) Hamaguri (clam) & & + & $\cdots$ & $\cdots$ & -- & -- & - & - & - & - \\
\hline (3) Asari (short-neck clam) & & + & - & $t$ & - & - & - & - & - & - \\
\hline (4) Mashijimi (corb shell) & & + & + & $\mathbf{t}$ & - & -- & - & - & - & - \\
\hline (5) Hotategai (scallop) & & $\mathrm{t}$ & - & - & - & - & - & - & - & - \\
\hline (6) Yariika (loligo) & & H & + & $t$ & - & - & - & - & $\cdots$ & - \\
\hline (7) Surumeika (squid) & & $H$ & + & $t$ & - & - & - & - & - & - \\
\hline (8) Argentine-surumeika (squid) & & + & + & $\mathrm{t}$ & - & - & - & $-\cdots$ & $\cdots \cdots$ & - \\
\hline (9) Torafukoika (Sepiidae) & & H & + & $t$ & - & - & - & - & - & - \\
\hline (10) Yoroppa-koika (Sepiidae) & & $\dot{+}$ & $\mathbf{t}$ & - & - & - & $\cdots \cdots$ & $\ldots$ & $\ldots .$. & - \\
\hline (11) Akaika (squid) & & - & - & $\cdots$ & -- & - & - & - & - & - \\
\hline Control & & - & - & - & - & - & - & - & - & - \\
\hline
\end{tabular}

Table 2. Specific inhibition of anti-akagai immune serum by the nuscle extract of akagai*t

\begin{tabular}{|c|c|c|c|c|c|c|c|c|c|c|c|}
\hline \multirow[t]{2}{*}{ Species of muscle ext. } & \multicolumn{11}{|c|}{ Dilution of muscle extract $(1 / 2 \mathrm{n})^{* 2}$} \\
\hline & $n:$ & 2 & 3 & 4 & 5 & 6 & 7 & 8 & 9 & 10 & Control \\
\hline Akagai (arkshell) & & - & - & - & - & + & H & It & H & H & \# \\
\hline Hamaguri (clam) & & H & 米 & H & H & $H$ & Itt & H & H & tit & H \\
\hline Asari (short-neck clam) & & $H$ & m & $H$ & 州 & \# & $\mathrm{Ht}$ & titt & H & H. & H \\
\hline Mashijimi (corb shell) & & $\mathrm{H}$ & \# & 曲 & 曲 & H & 册 & 米 & 曲 & 艮 & H \\
\hline Hotategai (scallop) & & H & H & 曲 & m & H & \# & H & H & H & H \\
\hline Yariika (loligo) & & H & H & $H$ & HH & H & 4 & H & HH & $-H \cdot$ & H \\
\hline
\end{tabular}

Table 3. Latex agglutination tests using various dilutions of anti-yarijka (loligo) immune rat serum and the latex particles sensitized with mollusc muscle extracts

\begin{tabular}{|c|c|c|c|c|c|c|c|c|c|c|c|c|c|}
\hline \multirow{2}{*}{$\begin{array}{l}\text { Latex (SDL 43) sensitized } \\
\text { with }\end{array}$} & \multicolumn{13}{|c|}{ Dilution of antiserum $\left(1 / 2^{n}\right)$} \\
\hline & $n:$ & 3 & 4 & 5 & 6 & 7 & 8 & 9 & 10 & 11 & 12 & 13 & Control \\
\hline Akagai (arkshell) & & + & + & $\mathbf{t}$ & - & - & - & - & - & - & - & - & - \\
\hline Hamaguri (clam) & & $\mathrm{t}$ & $\ldots$. & $-m$ & $\ldots . .$. & ..... & - & $\ldots$ & $\ldots$. & - & - & $\ldots .$. & - \\
\hline Asari (short-neck clam) & & H & $H$ & H & $\mathrm{t}$ & - & - & - & - & - & - & - & - . \\
\hline Mashijimi (corb shell) & & $\mathrm{t}$ & - & - & - & - & - & - & - & - & - & - & $\ldots$ \\
\hline Hotategai (scallop) & & - & - & - & - & - & - & - & - & - & - & - & - \\
\hline Yariika (loligo) & & H & $H$ & H & \# & 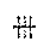 & 車 & 冊 & H & $\div$ & $\dashv$ & - & - \\
\hline Surumeika (squid) & & itt & H & $H$ & \# & + & $t$ & - & - & - & - & - & - \\
\hline Argentine-surumeika (squid) & & $H$ & H & + & - & - & - & $\ldots$ & - & - & - & - & - \\
\hline Torafukoika (Sepiidae) & & H & tit & H & \# & Hit & H & $t$ & - & - & -- & - & - \\
\hline Yoroppa-koika (Sepiidae) & & $\#$ & 卅 & $H$ & 卅 & $H$ & $\div$ & $\mathrm{t}$ & - & - & - & - & - \\
\hline Akaika (squid) & & - & - & - & - & - & - & - & - & - & - & - & - \\
\hline Control & & - & - & - & $\ldots$ & - & - & $\ldots$ & - & - & - & - & - \\
\hline
\end{tabular}


Table 4. Specific inhibition of anti-yariika serum by the muscle extract of yariika*

\begin{tabular}{|c|c|c|c|c|c|c|c|c|c|c|}
\hline \multirow[t]{2}{*}{ Species of muscle ext. } & \multirow[b]{2}{*}{$n:$} & \multirow[b]{2}{*}{1} & \multicolumn{7}{|c|}{ Dilution of muscle extract $\left(1 / 2^{n}\right)$} & \multirow[b]{2}{*}{ Control } \\
\hline & & & 2 & 3 & 4 & 5 & 6 & 7 & 8 & \\
\hline Yariika & & - & - & + & 4 & 世 & Hr & H & Ht & Ht \\
\hline Surumeika & & \# & \# & \# & 卅 & 册 & H & H & \# & th \\
\hline Argentine-surumeika & & + & H & 4 & H & H & H & $H$ & 世 & +4 \\
\hline Torafukoika & & \# & 4 & \# & 世 & $\#$ & \# & \# & th & 埥 \\
\hline Yoroppa-koika & & 世 & H & \# & i⿻ & \# & \# & \# & \# & 卌 \\
\hline Akaika & & m & 州 & \# & 世 & \# & 曲 & W & Hit & H \\
\hline
\end{tabular}

* Agglutination system: anti-yarika serum (diluted to $1 / 32$ ) and $\mathrm{Lx}$ sensitized with yariika.

Table 5. Latex agglutination tests using various dilutions of anti-torafukoika Sepia pharaonis immune rat serum and the latex particles sensitized with mollusc muscle extracts

\begin{tabular}{|c|c|c|c|c|c|c|c|c|c|c|c|c|}
\hline \multirow{2}{*}{$\begin{array}{l}\text { Latex (SDL 43) sensitized } \\
\text { with }\end{array}$} & \multirow[b]{2}{*}{$n:$} & \multirow[b]{2}{*}{3} & \multicolumn{10}{|c|}{ Dilution of antiserum $\left(1 / 2^{x}\right)$} \\
\hline & & & 4 & 5 & & 7 & & 9 & & & 12 & Control \\
\hline Akagai (arkshell) & & $\#$ & + & - & - & - & - & - & - & - & - & - \\
\hline Hamaguri (clam) & & + & - & - & - & - & - & - & - & - & - & - \\
\hline Asari (short-neck clam) & & $H$ & H & H & + & - & - & - & - & - & - & - \\
\hline Mashijimi (corb shell) & & - & - & - & - & - & - & - & - & - & - & - \\
\hline Hotategai (scallop) & & - & - & - & - & - & - & - & - & - & - & - \\
\hline Yariika (loligo) & & $\mathrm{Ht}$ & $\#$ & m & H & \# & m & H & + & $\mathbf{t}$ & - & - \\
\hline Surumeika (squid) & & H & $H$ & m & \# & 舟 & 4 & H & + & - & - & - \\
\hline Argentine-surumeika (squid) & & H & \# & m & \# & + & - & - & - & - & - & $\Leftrightarrow$ \\
\hline Torafukoika (Sepiidae) & & 世 & 世 & H & \# & \# & H & \# & H & + & - & - \\
\hline Yoroppa-koika (Sepiidae) & & 卅 & m & \# & m & 世 & $H$ & \# & $\#$ & + & - & - \\
\hline Akaika (squid) & & + & - & - & $\ldots$ & - & - & $\ldots$ & $\ldots$ & - & - & - \\
\hline Control & & - & - & - & - & - & - & - & - & - & - & - \\
\hline
\end{tabular}

Table 6. Agglutination inhibition test for the anti-torafukoika serum with the muscle extracts of squids*

\begin{tabular}{|c|c|c|c|c|c|c|c|c|c|c|}
\hline \multirow[t]{2}{*}{ Species of muscle ext. } & \multirow[b]{2}{*}{$n:$} & \multicolumn{9}{|c|}{ Dilution of muscle extract $\left(1 / 2^{n}\right)$. } \\
\hline & & 1 & 2 & 3 & 4 & 5 & 6 & 7 & 8 & Control \\
\hline Yariika & & - & - & + & H & \# & \# & \# & H & H \\
\hline Surumeika & & $t$ & + & H & Hitt & H & Ht & H & Ht & 讨 \\
\hline Argentine-surumeika & & $\mathrm{t}$ & + & \# & th & Htt & th & H: & H & \# \\
\hline Torafukoika & & - & - & + & $\#$ & m & 世 & \# & \# & 粗 \\
\hline Yoroppa-koika & & - & - & t & H & 曲 & Ht & H & H & 粼 \\
\hline Akaika & & H & H & 世 & H & H & 卅 & 册 & $H$ & 4 \\
\hline
\end{tabular}

- Agglutination system: anti-torafukojka serum (diluted to 1/32) and $L x$ sensitized with toraflikoika.

Table 7. Specific inhibition of anti-Antarctic krill immune rat serum by muscle extract of Antarctic krillit

Species of muscle ext.*3 Dilution of muscle extract $\left(1 / 2^{n}\right)^{* 2}$

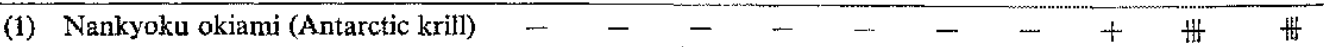

(2) Kurumaebi (tiger shrimp) $\quad$ H $\#$ H $\#$ \# $\#$ \# $\#$ \# $\#$

(3) Koraiebi (shrimp) H H H H H H H H H H

(4) Sakuraebi (spotted shrimp) _. $\quad+\quad$ H $\quad$ H H

*1 Specific inhibition was estimated in the aggiutimation system of anti-Antarctic krisl serum (dil. 1/16) and latex sensitized with. Antarctic krill, by adding the dilutions of muscle extracts.

*2 Concentration of proteins of each original muscle extract is $2.5 \mathrm{mg} / \mathrm{ml}$.

*3 Latin name: (1) Euphausia superba, (2) Penoeus japonicus, (3) Penoeus orientalis, (4) Sergestes lucens. 
Table 8. Latex agglutination reactions between various dilutions of molluse muscle extract and latex particles sensitized with anti-akagai (arkshell) immune rat serum

\begin{tabular}{|c|c|c|c|c|c|c|c|c|c|c|}
\hline \multirow{2}{*}{ Species of muscle ext. } & \multicolumn{10}{|c|}{ Dilution of muscle extract $\left(1 / 2^{n}\right)^{*}$} \\
\hline & $n:$ & 1 & 2 & 3 & 4 & 5 & 6 & 7 & 8 & Control \\
\hline Akagai (arkshell) & & \# & \# & H & + & $\mathbf{t}$ & - & - & - & - \\
\hline Hamaguri (clam) & & - & - & - & - & - & - & - & 一 & - \\
\hline Asari (short-neck clam) & & - & - & - & - & - & - & - & - & - \\
\hline Mashijimi (corb shell) & & - & - & - & - & - & - & - & - & - \\
\hline Hotategai (scallop) & & - & - & - & - & - & - & - & - & - \\
\hline Surumeika (squid) & & - & - & - & - & - & - & - & - & - \\
\hline
\end{tabular}

* Original dilution of extracts: $2.5 \mathrm{mg}$ protein/ml.

species. For instance, the anti-torafukoika immune serum agglutinated the $\mathrm{Lx}$ sensitized with yoroppakoika or yariika to the same degree as it agglutinated the $\mathrm{Lx}$ sensitized with torafukoika (see Table 5). Moreover, the agglutination inhibition tests also failed to reveal the species specificity (see Table 6). To overcome this problem, more specific antiserums must be prepared by improving the immunization method.

Crustaceans: The $\mathrm{Lx}$ agglutination tests were carried out by using the antigen-sensitized Lx and the antiserums of rats immunized with muscle extracts of kurumaebi, koraiebi, sakuraebi, and nankyoku okiami. From the results, the species specificities of these sera were detected and it was shown that the antigenicity of nankyoku okiami was very different from the shrimps (see Table 7 ).

\section{Antibody-Sensitized Lx Agglutination}

If the titer of antiserum was relatively low, $\mathrm{Lx}$ was sensitized by crude $\gamma$-globulin solution prepared from the antiserum. However, diluted antiserum was used directly for sensitizing the Lx when titer was high. These antibody-sensitized Lx particles were agglutinated specificaliy by homologous antigen solutions. For instance, the muscle extract of akagai specifically agglutinated the $\mathbf{L x}$ sensitized with the anti-akagai serum, however, those the other species did not react at all (see Table 8).

\section{Discussion}

\section{Sensitivity of Lx Agglutination Test}

The passive agglutination reaction, brought about by the agglutination reaction of particles such as erythrocyte, collodion, bentonite or latex (coated with antigen or antibody), with the homologous antibody or antigen respectively, is usually more sensitive than the precipitation reaction, such as the ring test or immunodiffusion test. In this work, antisera were also examined by microimmunodiffusion method, and the critical dilutions of sera detectable to homologous antigen by this method are shown in Table9. Our results clearly show that without exception, the Lx agglutination method is by far more sensitive in comparison with the micro-immunodiffusion method. For instance, anti-akagai serum diluted 500 fold was able to agglutinate the $\mathrm{Lx}$ sensitized with akagai muscle extract (Table 1), while it barely detected the homologous antigen at the two fold dilution by the micro-immunodiffusion method (Table 9). In the case of the anti-yariika serum,

Table 9. Titers of antisera determined by the micro-immunodiffusion method

\begin{tabular}{|c|c|c|c|c|c|c|c|c|c|c|c|}
\hline \multirow{2}{*}{ Antiserum } & \multicolumn{2}{|c|}{ Antigen: ext. of muscle } & \multicolumn{9}{|c|}{ Dilution of antiserum $\left(1 / 2^{n}\right)$} \\
\hline & Species & $\begin{array}{c}\text { Concentration of } \\
\text { protein } \mathrm{mg} / \mathrm{m} /\end{array}$ & $n:$ & 0 & 1 & 2 & 3 & 4 & 5 & 6 & 7 \\
\hline \multirow[t]{2}{*}{ Anti-akagai } & Akagai & 16.8 & & + & + & $\cdots$ & - & - & $\rightarrow$ & - & $-*$ \\
\hline & & 2.5 & & + & - & - & - & - & - & - & $\cdots$ \\
\hline \multirow[t]{2}{*}{ Anti-yarika } & Yariika & 14.3 & & + & + & + & + & - & - & - & - \\
\hline & & 2.5 & & + & + & + & + & - & - & - & - \\
\hline \multirow[t]{2}{*}{ Anti-torafukoika } & Torafukoika & 13.6 & & + & - & - & - & - & - & - & - \\
\hline & & 2.5 & & + & - & - & - & - & - & - & - \\
\hline
\end{tabular}


Tahle 10. Latex agglutination reaction between various dilutions of egg white and latex particles sensitized with anti-aoumigame (sea-turtle) immune rat serum

Species of egg white
Aoumigame*

it was detectable to homologous antigen at the 4,000 fold dilution by means of $\mathrm{Lx}$ agglutination (Table 3), but it scarcely detected the same antigen at the 8 fold dilution by the micro-immunodiffusion method (Table 9).

\section{Application to the Verification of Meat Products}

In general, the passive agglutination reactions, because of their high sensitivity, have been used in the fields of clinical and forensic medicine. For other purposes, however, as in the verification of meat products, several precipitation reactions have mostly been used to identify the origin of material meat ${ }^{11-153}$; seldom has the passive agglutination reaction been applied. One of the rare instances in KaRPAs' work $^{10)}$ where he used the hemagglutination reaction of formalinized sheep erythrocytes sensitized with antigen to identify the origin of sausage meat.

The authors have employed the $\mathrm{Lx}$ agglutination test in species identification, and the above mentioned results showed that the test was useful to identify the species of molluscs and crustaceans. However, in the development of other studies using $\mathrm{Lx}$ agglutination, futher investigation has to be carried out especially on the problems concerned with the unspecific agglutination occurring with muscle extracts of some teleost species.

\section{Application to the Other Fields}

The Lx particles and Lx agglutination test have many favorable properties, i.e. non-antigenicity of Lx, high sensitivity and specificity, and stability of the sensitized Lx. Thus the $\mathbf{L x}$ agglutination reaction can also be employed in the following useful fields: 1) detection of trace amount of antigen in the purification process, 2 ) identification and estimation of low titer antibody, such as that produced in fish infected by pathogenic bacteria and 3) comparative studies of proteins and enzyme. For instance, the egg white proteins of aoumigame (sea turtle, Chelonia mydas) were found by Fuku$N A G A^{17,18)}$ to have different physicochemical properties from those of chicken and quail. Results of the antibody-sensitized Lx agglutination tests on the above mentioned proteins, as shown on Table 10, also revealed differences in immunological properties.

\section{Acknowledgment}

The authors wish to acknowledge Dr. OKaDA's encouragement and helpful suggestions in the preparation of this manuscript.

\section{References}

1) J. M. Singer and C. M. Plotz: Am.J.Med., 21, $888-892$ (1956).

2) C. M. Plotz and J. M. Srnger: Am. J. Med., 21, 893-896 (1956)

3) J. D. Gerber, R. E. RiLEY, and R. D. Jones: Appl. Microbiol., 24, 191-197 (1972).

4) C.W. Y YH: Japanese J. Legal Med., 30, 55-66 (1976).

5) S. SEGRE: J. Immunol., 78, 304-309 (1976).

6) S. Suzuki, H. SaKakibara, and S. HorTa: $d$. Clinical Microbiol., 6, 332-336 (1977).

7) A. Suzukr: in "Verification of Marine Foods" (ed. by The Japanese Society of Scientific Fisheries), Koseisha Koseikaku, Tokyo, 1979, pp. 46-58.

8) S. Matsuzawa, H. Kimura, Y. Ito, and C.W. YeH: Japanese J. Legal Med., 29, 103-109 (1975).

9) H. Kimura and S. Matsuzawa: Japanese J. Legal Med., 31, 47-53 (1977).

10) K. HeIve and H. G. ScHwCK: in "Handbook of Experimental Immunology" (ed, by D.M. WeIR), 2nd ed., Blackwell Scientific Publications, Oxford, 1973, pp. 6.1-6.11.

11) A. Weinstocx: J. Milk Food Technol., 16, 257259 (1953).

12) H. Murakami, F. Umeki, T. Nakamura, and M. Haruta: J. Food Hyg. Soc, 10, 434-439 (1969).

13) M.B. HeLm, M.O. WARNecke, and R.L. Saffie: J. Food Sci., 36, 998-1000 (1971).

14) A. R. HAYDEN: J. Food Sci., 42, 1189-1192 (1977).

15) A. R. HAXOEN: J. Food Sci., 43, 476-478, 492 (1978).

16) A. B. Karpas, W. L. Myers, and D. Segre: J. Food Sci., 35, 150-155 (1970),

17) T. FuKunAGA and K. KoGA: Bull. Facul Agricul. Kagoshima Univ., 24, 89-105 (1974).

18) T. FuKunAGA and K. Koga: Bull. Facul Agricul. Kagoshima Univ., 24, 107-132 (1974). 